\title{
Light exercise causes adaptive changes in muscles of young Brasileiro de Hipismo horses
}

\author{
Atividade física leve causa mudanças adaptativas musculares em eqüinos jovens da raça \\ Brasileiro de Hipismo
}

\author{
Flora Helena de Freitas D‘Angelis ${ }^{\mathrm{I}}$ Marco Augusto Giannoccaro da Silva ${ }^{\mathrm{II}}$ Carla Braga Martins ${ }^{\mathrm{II}}$ \\ Guilherme de Camargo Ferraz ${ }^{\mathrm{I}}$ João Ademir de Oliveira ${ }^{\mathrm{III}}$ Isabel Cristina Boleli ${ }^{\mathrm{I}}$ \\ José Corrêa de Lacerda-Neto ${ }^{\mathrm{II}}$ Antonio de Queiroz-Neto ${ }^{\mathrm{I}}$ *
}

\begin{abstract}
This study aimed to determine the changes in the gluteus medius of 4 year-old Brasileiro de Hipismo (BH) horses submitted to light physical activity for 10 months. The study involved 11 horses from the "Nove de Julho" Battalion of the Military Police of São Paulo State (PM-SP). Percutaneous muscle biopsy was performed in horses at maintenance and in those that had participated in routine police work for 10 months with the PM-SP. Fragments of the left gluteus medius muscle was removed at depths of $20 \mathrm{~mm}$ and $60 \mathrm{~mm}$. To determine the fiber types, the histochemical analyses were performed for myofibrillar adenosine triphosphatase (mATPase) and nicotinamide adenine dinucleotide tetrazolium reductase (NADH-TR). The morphometry of the fibers was performed by calculating the cross sectional area (CSA), relative frequency distribution ( $F$ ) and relative cross-sectional area (RCSA). After the period of physical activity, type IIA fibers showed an increase in F and RCSA at both depths. The type I fibers showed a decrease in $F$ at a depth of $60 \mathrm{~mm}$ and the type IIX fibers showed no change in $F$ at the two depths. With regard to the results for RCSA, type I and IIX fibers also did not show alterations after 10 months of light physical activity. Low intensity physical activity produced significant adaptations in the gluteus medius muscle of horses of the $\mathrm{BH}$ breed, including changes in metabolic and contractile properties as evidenced by the increase in the area occupied by type IIA fibers at both depths of the biopsy.
\end{abstract}

Key words: Brasileiro de Hipismo breed, horse, histochemistry, gluteus medius muscle, low intensity exercise.

\section{RESUMO}

Este estudo objetivou determinar as adaptações do músculo gluteus medius de cavalos da raça Brasileiro de Hipismo $(\mathrm{BH})$, que participaram de atividades físicas leves por 10 meses.
Foram utilizados 11 eqüinos, machos, da raça $\mathrm{BH}$ e com idade de 4 anos, provenientes do "Batalhão Nove de Julho" da Polícia Militar do Estado de São (PM-SP). Realizou-se a biópsia muscular percutânea nos animais inativos $e$, após participarem das atividades de ronda e policiamento desenvolvido pela PMSP por 10 meses, foram retirados fragmentos do músculo gluteus medius nas profundidades de $20 \mathrm{~mm}$ e $60 \mathrm{~mm}$. Para a determinação dos tipos de fibra muscular, foram feitas análises histoquímicas por meio das técnicas de adenosina trifosfatase miofibrilar (mATPase) e nicotinamida adenina dinucleotídeo tetrazólio redutase (NADH-TR). Na análise morfométrica das fibras, calculou-se a área de secção transversal (AST), a freqüência média $(F)$ e a área de secção transversal relativa (ASTR). Após o período de atividade física, as fibras tipo IIA apresentaram aumento da F e da ASTR nas duas profundidades. As fibras tipo I apresentaram diminuição da $F$ na profundidade de 60mm e as fibras tipo IIX não sofreram alteração da $F$ nas duas profundidades. A ASTR das fibras tipo I e IIX não apresentaram alteração após os 10 meses. A atividade física de baixa intensidade produziu adaptações significativas no músculo gluteus medius de cavalos da raça $\mathrm{BH}$, incluindo mudança nas propriedades metabólicas e contráteis evidenciadas pelo aumento da área ocupada pelas fibras tipo IIA, nas duas profundidades de biópsia.

Palavras-chave: Brasileiro de Hipismo, cavalo, histoquímica, gluteus medius, exercício de baixa intensidade.

\section{INTRODUCTION}

The Brasileiro de Hipismo (BH) breed has been registered since the 1970s with the creation of the Brazilian Association of Breeders of the Hipismo Horse

\footnotetext{
IDepartamento de Morfologia e Fisiologia Animal, Faculdade de Ciências Agrárias e Veterinárias (FCAV), Universidade Estadual Paulista (UNESP). Via de acesso Prof. Paulo Donato Castellane, 14884-900. Fone: 55-021-16-32092654, fax: 55-021-1632024275. E-mail: aqueiroz@fcav.unesp.br.*Autor para correspondência.

IIDepartamento de Clínica e Cirurgia, FCAV, UNESP, Jaboticabal, SP, Brasil.

IIIDepartamento de Ciências Exatas, FCAV, UNESP, Jaboticabal, SP, Brasil.
} 
(ABCCH, 1998). Despite excellent performance, not only in jumping contests but also those for dressage, 3-days event and pleasure riding, little is known about the muscular characteristics of the animals of this breed. D'ANGELIS et al. (2006) demonstrated that the gluteus medius muscle of sedentary horses of the $\mathrm{BH}$ breed aged between 2 and 3 years showed a greater glycolytic metabolism with better anaerobic capacity, which can be explained by the greater proportion of type IIX fibers. The same authors also report that this appears to be due to the large genetic influence of Thoroughbred breeding in the formation of the $\mathrm{BH}$ horse. In addition, these animals were young and at maintenance, factors that could have influenced the results.

RIVERO et al. (1995) reported that horses adapted to endurance tests, with better results of athletic performance, have a large aerobic capacity and, proportionally, less anaerobic capacity in the gluteus medius muscle compared to horses with bad performance. The better performance was related to the larger proportion of type I and IIA fibers in this muscle. SERRANO et al. (2000) proposed that endurance training in horses induces structural changes in the expression of isoforms of myosin heavy chain (MHC), involving transformations of MHCs of fast twitch to MHCs of slow twitch and that these changes depend on the duration and increase in activity, which are then reversed 3 months after the end of training. In another experiment, LINDHOLM et al. (1983) observed that 2 year old Thoroughbred horses showed an increase in the proportion of type IIA fibers and increase in oxidative capacity during a 12-months period of aerobic and anaerobic conditioning. In addition, Standardbred Trotter horses, 6 to 8 years old, that were active in racing events, developed a greater percentage of type IIA fibers and higher oxidative capacity in comparison with inactive horses of the same breed (ÉSSEN-GUSTAVSSON et al., 1980). Although the muscle fibers composition is directly related to genetic characteristics and the performance of each breed in a particular sport, it is known that training increases the proportion of oxidative type IIA fibers and lowers the proportion of type IIB fibers in locomotor muscles, regardless the breed (ÉSSEN-GUSTAVSSON et al., 1980; HENCKEL, 1983).

Regarding $\mathrm{BH}$ horses, no studies were found on the biochemical and structural composition of skeletal muscle of athletic horses of the $\mathrm{BH}$ breed, no reports were found regarding to adaptive changes in muscle fibers as a result of a low intensity physical activity.

The aim of this study was to determine the effect of exercise activity during routine police work for 10 months on the structural and metabolic pattern of skeletal striated muscle fibers in the gluteus medius muscles of young $\mathrm{BH}$ horses by histochemical analyses of m-ATPase and NADH-TR.

\section{MATERIAL AND METHODS}

The study included 11 no-exercised horses of BH breed, males (9 geldings and 2 stallions) with an approximate age of 4 years at the start of the experiments and a body weight of $490 \pm 20 \mathrm{~kg}$. The horses were from the 'Nove de Julho' Battalion of the Military Police (PM), São Paulo State (SP). The animals selected did not show signs clinical signs of lameness. They were kept in individual stalls up to the end of the experimentation period. Daily feed consisted of $6 \mathrm{~kg}$ of concentrate $^{\mathrm{a}}$ (Crude protein - minimum 15\%, Ethereal extract - minimum 3\%, Crude fiber maximum 12\%, Digestible energy - minimum $3100 \mathrm{kcal} / \mathrm{kg}$ ) and $4 \mathrm{~kg}$ of 'coast cross' hay, both divided into two portions per day, plus mineralized salt and water ad libitum.

All horses were exercised for a period of 10 months by the Military Police of São Paulo State in which they used the horses in routine police work. Each one was always exercised by the same person, 10 hours daily at $90 \%$ at walk 4 to 5 times per week, with intervals for adequate feeding two times a day. Every 15 days, a specific training for 1 hour and 30 minutes was performed with $70 \%$ exercise at trot, $20 \%$ at gallop and $10 \%$ at walk. No lameness was observed during the whole period in which the animals participated in the regimen of routine Police work

A percutaneous muscle biopsy was performed using a $6.0 \mathrm{~mm}$ Bergström-type needle. Two muscle biopsies were taken, one before (resting) and another after 10 months of light physical activity, when fragments of the left gluteus medius muscle were taken at depths of first $20 \mathrm{~mm}$ and then $60 \mathrm{~mm}$. The technique consisted of the collection of fragments from the gluteus medius muscle at $15 \mathrm{~cm}$ caudo-dorsal to the coxae tuber at an angle of $45^{\circ} \mathrm{C}$. The fragments were imersed in tissue freezing medium ${ }^{\mathrm{b}}$ to create a protective film, and then frozen in prechilled hexane for approximately 40 seconds (DUBOWITZ, 1985), kept frozen in liquid nitrogen and later stored in a deep freezer ${ }^{\mathrm{c}}$ at $-70^{\circ} \mathrm{C}$ until processed. The interval between obtaining and freezing biopsies was around 2-3 minutes in order to avoid problems with the muscle sample (DUBOWITZ, 1985). The samples were processed in the Department of Animal Morphology and Physiology, FCAV-UNESP, Campus Jaboticabal, SP.

Histochemical analysis was used to identify type I, IIA and IIX fibers. The terminology IIX instead 
of IIB was used to maintain a consistent nomenclature across different species and because the myosin heavy chain isoform expressed in these fibers is more closely related to the rat miosyn IIX than to the rat IIB (RIVERO et al., 1999). The oxidative potential of the skeletal muscle fibers was determined by nicotinamide adenine dinucleotide tetrazolium reductase (NADH -TR) technique described by NOVIKOFF et al. (1961). The mATPase assay modified by D’ANGELIS et al. (2005) was used to investigate the contractile characteristic of the fibers. For both the NADH-TR and the mATPase assay, two semi-serial cross sectional samples of $12 \mu \mathrm{m}$ thickness were obtained from the gluteus medius muscle using a cryostat ${ }^{\mathrm{d}}$ at $-20^{\circ} \mathrm{C}$.

The variables examined were: cross sectional area (CSA) of each fiber type, relative frequency distribution ( $F$ ) of each fiber type per microscopic field analyzed and relative cross-sectional area (RCSA) that a fiber type occupied in the biopsy specimens. The mean CSA of the fibers was calculated in $\mu \mathrm{m}^{2}$, from the measurement of 100 cross sections of each type of fiber. A mean $F$ was obtained as the percentage of the total number of fibers present per microscopic field analyzed, whereby three fields measuring $585,000 \mu \mathrm{m}^{2}$ selected randomly from histological sections were examined. The RCSA occupied for each fiber type was determined as a percentage according to RIVERO et al. (1993a). The morphometric data were obtained from microphotographic images of the histological sections and evaluated by an image analyzing program ${ }^{\mathrm{f}}$.

The results on morphometry of the biopsied muscle were evaluated by analysis of variance carried out using PROC GLM of Statistical Analysis Systems software (SAS, 2002). The statistics model included the effect of training and of the depth at which the muscle sample was obtained. Tukey's test $(\mathrm{P}<0.05)$ was used for comparison of the variables regarding the different fiber types in the same group and at the same depth, and Student's t-test was used for comparison of the means of the same variables at different depths, as was the effect of training. The level of significance was set at $5 \%$.

\section{RESUITS}

Both NADH-TR (Figure 1A) and mATPase (Figure 1B) staining showed the presence of myofibers similar to type IC (of intermediary color intensity, between I and IIA fibers), as well as IIA-X hybrid myofibers (color intensity between IIA and IIX). Since they occurred at low frequencies (less than 5\%) and considering their metabolic characteristics, were therefore included in the percentages of type I and type IIX fibers, respectively.

At a depth of 20mm, type IIA and IIX fibers, showed similar $\mathrm{F}$ which were significantly higher than that of type I fibers (Table 1) in the non-exercises horses. The same occurred at the same biopsy depth for the group of animals after 10 months of physical activity. However, for the depth of $60 \mathrm{~mm}$ in non-exercise horses, type IIA fibers showed a higher F than that of type IIX fiber which, in turn were more frequent than type I fibers. Similar results were obtained for exercised horses at a depth of $60 \mathrm{~mm}$. Considering the $\mathrm{F}$ between the two biopsy depths in the non-exercised group, only type IIA fibers showed a significantly higher $\mathrm{F}(\mathrm{P}=0.01)$ for a depth of $60 \mathrm{~mm}$, while type I and IIX fibers did not show alterations due to depth. In the exercised group, if we consider the two depths for muscle biopsy, it can be seen that at $60 \mathrm{~mm}$, the $\mathrm{F}$ was significantly higher than at $20 \mathrm{~mm}$ for type IIA fibers $(\mathrm{P}=0.003)$ and lower for type IIX fibers $(\mathrm{P}=0.013)$. There was no significant difference in $\mathrm{F}$ for type I fibers

The effect of light physical exercise on the F of different types of muscle fibers at a depth of $20 \mathrm{~mm}$, was evaluated and there was a significant decrease in type I fibers ( $\mathrm{P}=0.048)$, a significant increase in type IIA fibers $(\mathrm{P}=0.012)$, and no effect on type IIX fibers. However, at a depth of $60 \mathrm{~mm}$, a significant increase was seen for type IIA fibers $(\mathrm{P}=0,041)$, while type I fibers and type IIX fibers showed no change in $\mathrm{F}$ after 10 months of light exercise.

The results for the CSA of the type I, IIA and IIX fibers are given in table 1 . Comparing the results for the non-exercised animals, at both biopsy depths, the type IIX fibers showed a greater CSA than type I and IIA fibers, which in turn had similar CSA. After training, at a depth of $20 \mathrm{~mm}$, showed that the CSA of type IIX fibers was significantly greater than the CSA of type I fibers and similar to the CSA of type IIA fibers. However, in comparing the CSA of fibers at a depth of $60 \mathrm{~mm}$, type IIX fibers showed a significantly greater CSA, followed by type IIA fibers and type I fibers.

When the effect of the biopsy depth on CSA for the three types of fibers was examined in nonexercised horses, no difference was observed. The same result was found after the period of 10 months of light physical activity. No difference was observed on the effect of physical activity on the CSA for the three types of fibers at a depth of $20 \mathrm{~mm}$. However, for the depth of $60 \mathrm{~mm}$, there was an increase in CSA for type IIA fibers $(\mathrm{P}=0.005)$, but not change however for CSA of type I fibers and type IIX fibers, after 10 months of light physical activity.

The results for RCSA (Table 1 ) in the group of horses before training at the depth of $20 \mathrm{~mm}$, showed 


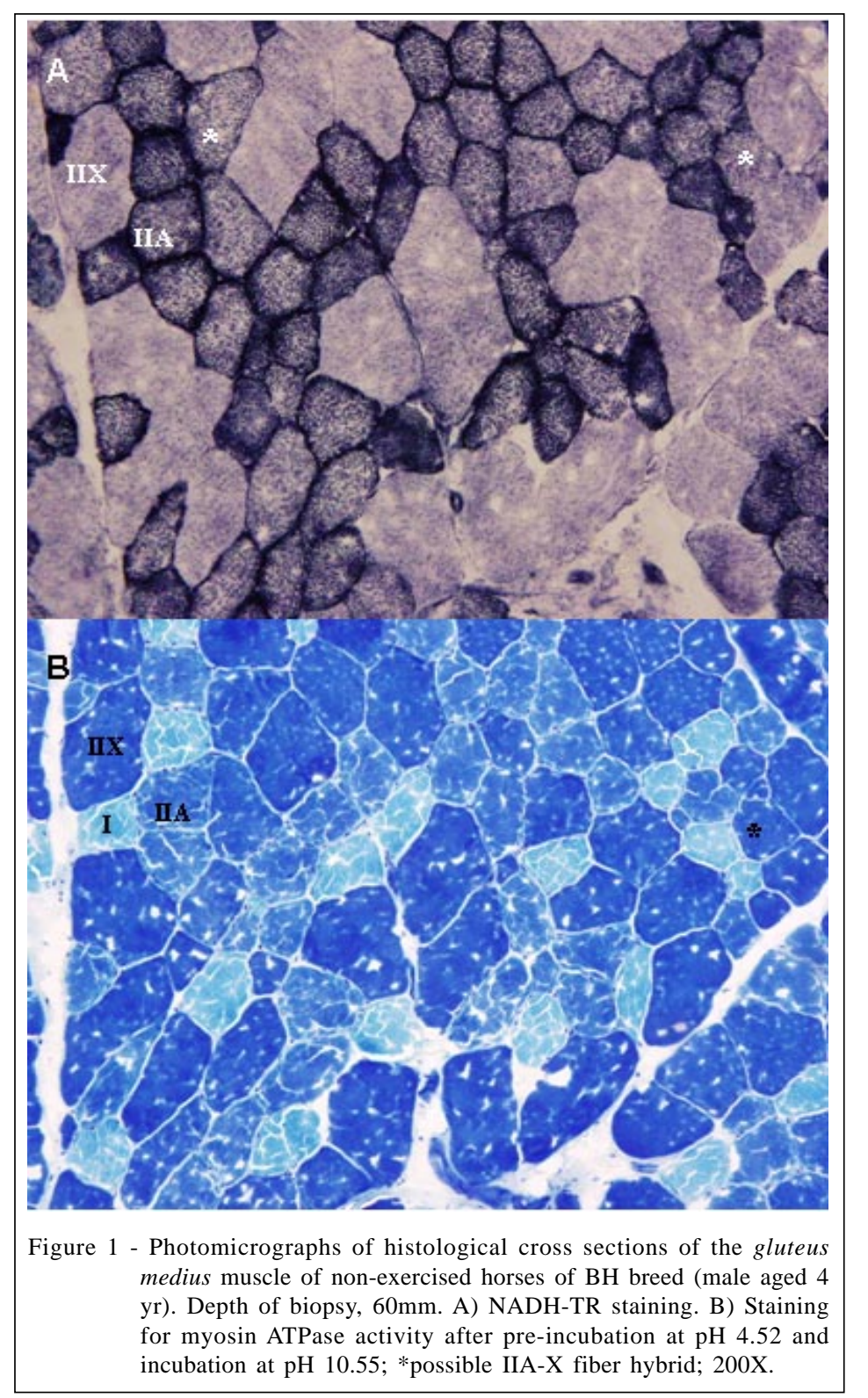

that the RCSA of type IIX fibers was greater than that of the type IIA fibers which in turn was greater than that of type I fibers. For a depth of 60mm in this group, it is noted that the RCSA was similar for type IIA and IIX fibers and greater than the RCSA of type I fibers. The same was observed at the two depths after the training period of 10 months.

When the variation between the two depths was examined in the group of non- exercised animals, a greater RCSA was seen for type IIA fibers $(\mathrm{P}=0.012)$ and lower RCSA for type IIX fibers $(\mathrm{P}=0.012)$ at a depth of $60 \mathrm{~mm}$, while no significant difference in RCSA was observed for type I fibers. The same occurred in the exercised group. In the evaluation of the effect of light physical activity on the RCSA of the three types of fibers, at a depth of $20 \mathrm{~mm}$, there was no significant difference for type I and IIX fibers, but an increase was seen for type IIA fibers $(\mathrm{P}=0.012)$. Similarly, at a depth of $60 \mathrm{~mm}$, there was an increase in RCSA for type IIA fibers $(\mathrm{P}=0.050)$, but no significant variation in RCSA for type I and IIX fibers, after 10 months of light physical activity.

\section{DISCUSSION AND CONCLUSIONS}

The scientific literature makes reference to the study of muscle biopsies in different breeds of horses and the effect of training in muscle composition 
Table 1 - mean frequency (\%), cross sectional area $\left(\mu \mathrm{m}^{2}\right)$ and relative cross-sectional area (\%) of each fiber type in a biopsy of the gluteus medius muscle of male horses of the Brasileiro de Hipismo breed, with ages of about 4 years. Biopsies were taken at depths of $20 \mathrm{~mm}$ and $60 \mathrm{~mm}$, before and after 10 months of low intensity physical activity.

\begin{tabular}{|c|c|c|c|c|}
\hline \multirow[t]{3}{*}{ Muscle variable } & \multicolumn{2}{|c|}{--------Non-exercised-------- } & \multicolumn{2}{|c|}{----------Exerc ised----------- } \\
\hline & $20 \mathrm{~mm}$ & $60 \mathrm{~mm}$ & $20 \mathrm{~mm}$ & $60 \mathrm{~mm}$ \\
\hline & $(n=11)$ & $(n=11)$ & $(n=11)$ & $(n=11)$ \\
\hline \multicolumn{5}{|c|}{ Frequency fiber type (\%) } \\
\hline I & $23.5 \pm 6.2^{\mathrm{A}}$ & $20.1 \pm 3.2^{\mathrm{A}}$ & $19.1 \pm 5.7^{\mathrm{A}^{*}}$ & $18.5 \pm 3.8^{\mathrm{A}}$ \\
\hline ПIА & $37.3 \pm 7.1^{\mathrm{BH}}$ & $44.7 \pm 6.8^{\mathrm{B}}$ & $42.2 \pm 4.1^{\mathrm{B} \# *}$ & $48.6 \pm 4.8^{\mathrm{B}^{*}}$ \\
\hline IIX & $39.3 \pm 6.3^{\mathrm{B}}$ & $35.3 \pm 7.3^{C}$ & $38.8 \pm 3.8^{\mathrm{B} \#}$ & $32.9 \pm 5.7^{\mathrm{C}}$ \\
\hline \multicolumn{5}{|c|}{ Cross sectional area $\left(\mu \mathrm{m}^{2}\right)$} \\
\hline I & $3544 \pm 654^{\mathrm{A}}$ & $3597 \pm 1082^{\mathrm{A}}$ & $3552 \pm 699^{A}$ & $3527 \pm 635^{\mathrm{A}}$ \\
\hline IIA & $4937 \pm 799^{\mathrm{A}}$ & $4458 \pm 699^{\mathrm{A}}$ & $5333 \pm 1206^{\mathrm{B}}$ & $5698 \pm 1088^{B^{*}}$ \\
\hline IIX & $7010 \pm 1063^{B}$ & $6147 \pm 1081^{\mathrm{B}}$ & $6889 \pm 1118^{\mathrm{B}}$ & $7080 \pm 1736^{\mathrm{C}}$ \\
\hline \multicolumn{5}{|c|}{ Relative cross section area (\%) } \\
\hline I & $16.2 \pm 5.9^{\mathrm{A}}$ & $14.6 \pm 2.5^{\mathrm{A}}$ & $12.6 \pm 5.4^{\mathrm{A}}$ & $11.5 \pm 4.6^{\mathrm{A}}$ \\
\hline IIA & $32.6 \pm 6.8^{\mathrm{B} *}$ & $41.3 \pm 7.9^{\mathrm{B}}$ & $39.8 \pm 4.1^{\mathrm{B} * *}$ & $47.4 \pm 7.5^{\mathrm{B}^{*}}$ \\
\hline IIX & $51.2 \pm 7.2^{\mathrm{CH}}$ & $44.2 \pm 8.6^{\mathrm{B}}$ & $47.7 \pm 6.7^{\mathrm{B} \#}$ & $41.1 \pm 8.7^{\mathrm{B}}$ \\
\hline
\end{tabular}

$\mathrm{n}$ : number of observations. Capital letters in the same columns, are used for comparison among the three different fiber types analyzed at the same depth by Tukey's test $(\mathrm{P}<0.05)$. ${ }^{\#}$ Indicates a significant difference $(\mathrm{P}<0.05)$ between the depths in the same experimental group by the paired t-test. *Indicates a significant difference $(\mathrm{P}<0.05)$ when compared to values obtained in the group of inactive horses at the same depth, by the paired t-test.

(HENCKEL, 1983; RIVERO et al., 1995; SERRANO et al., 2000; CASTRO et al., 2004). Yet, there are no reports on the typing and morphometry of muscle fibers in $\mathrm{BH}$ horses regarding the effect of training or any physical activity, which makes this work one of the first showing that even a period of 10 months of light physical activity is capable of producing changes in the gluteus medius muscle fiber distribution in $\mathrm{BH}$ horses.

This study shows that, in general, there is a greater frequency and mean relative cross-sectional area of type IIX myofibers, in the more superficial portions of the gluteus medius muscle, which apparently is due to a lower frequency and relative cross-sectional area for type IIA fibers. This observation agrees with various authors who find that the distribution of the different types of fibers is not homogeneous in the muscle (RIVERO et al., 1993b; VAN DEN HOVEN et al., 1985). These authors also observed that the deep parts of the gluteus medius muscle have greater aerobic pattern and a greater percentage of oxidative type I fibers, a finding that was not observed in the present study, although a greater number of type IIA fibers, also oxidative, was found at a depth of $60 \mathrm{~mm}$. The authors also observed that superficial parts of this muscle show glycolytic characteristics and a predominance of type IIX fibers. It is evident that there is a need to standardize the depth at which biopsies should be taken for analysis of muscle composition.

On other the hand, the effect of physical activity on the frequency of muscle fiber types can be observed at the two biopsy depths, characterized by the increase in the percentage of type IIA fibers. This finding corroborates those of various authors (ÉSSENGUSTAVSSON et al., 1983; SERRANO et al., 2000) who also observed an increase in the percentage of and the area occupied by type IIA fibers. However, these authors also found a decrease in the frequency of type IIX fibers after a training period, which was not evident statistically in BH horses after physical activity. It is possible that the lack of effect of physical activity on type IIX fibers is due to differences among the breeds studied, as well as to the type of exercise that the horses were submitted.

Another factor that can also be attributed to the type of physical activity and/or the characteristics of the breed, is the lack of effect of physical activity on the percentage of type I myofibers, since SERRANO et al. (2000) observed that after a prolonged training period there was an increase in this type of fiber with a loss of type IIX fibers.

In relation to the diameter of the fibers, there was hypertrophy of type IIA fibers after 10 months of 
low intensity physical activity at a depth of $60 \mathrm{~mm}$. Similar results were obtained by ÉSSEN-GUSTAVSSON et al. (1983) in Thoroughbred foals in a training program. This finding, associated with the greater proportion of type IIA fibers explain the results regarding the mean relative cross-sectional area of these fibers which was found to be increased after the period of physical activity, at both depths studied.

The results of morphometric evaluations of fiber types obtained in our study show evidence of an adaptive response of the gluteus medius muscle to prolonged physical activity of low intensity, indicating that there was an improvement in oxidative capacity for this muscle in the BH horse. It is important to point out also that the present study used mostly geldings. Since the literature does describe differences with respect to sex and sex hormones in the structural and biochemical composition of skeletal muscle fibers. Therefore, further studies should be conducted in females of the same breed under physical training stimulus.

\section{ACKNOWLEDGEMENTS}

Research supported by Fundation de Amparo à Pesquisa do Estado de São Paulo (FAPESP). The authors thank the 'Nove de Julho' Battalion of the Military Police (PM), São Paulo State (SP) for the use of their animals; the Maria Paula M. Scandar of the Laboratório de Neuropatologia/Departamento de Patologia (FMRP-USP, RP) for technical assistance.

\section{SOURCES AND MANUFACTURES}

${ }^{a}$ Equitage, Guabi, SP, Brazil

${ }^{\text {b} B i o-f r e e z e r ~ F o r m a ~ S c i e n t i f i c, ~ I n s t r u c o m ~ I n d . ~ C o m . ~ L t d a, ~ S P, ~}$ Brazil

cJung, Leica Iintruments, SP, Brazil

${ }^{d}$ Mícron gmbH - H1599 OM, 69190, Walldorf, Germany

${ }^{\mathrm{e} C}$ Camedia Olympus 95-98 ME, Olympus, SP, Brazil

${ }^{\mathrm{f} I m a g e}$ pro Plus, Cybernetica, SP, Brazil

\section{ANIMAL WELFARE APPROVAL}

The present work was approved by Ethical and Animal Welfare Commission (CEBEA), of Faculdade de Ciências Agrárias e Veterinárias (FCAV/UNESP-Jaboticabal), Jaboticabal, SP, Brazil (Process \# 016611).

\section{REFERENCES}

ABCCH. Associação Brasileira de Criadores do Cavalo Brasileiro de Hipismo. São Paulo: Fracta Produções Visuais, 1998. 46p.

CASTRO, I.N. et al. Muscle fiber types in Crioulo horses. $\mathbf{J}$ Equine Vet Sci, v.24, p.204-209, 2004.
D‘ANGELIS, F.H.F. et al. Aerobic training, but not creatine supplementation, alters the gluteus medius muscle. J Anim Sci, v.83, p.579-585, 2005.

D’ANGELIS, F.H.F. et al. Composição de fibras musculares esqueléticas de eqüinos jovens da raça Brasileiro de Hipismo. Arq Bras Med Vet Zootec, v.58, p.672-674, 2006.

DUBOWITZ, V.A. Muscle biopsy: a practical approach. London: Bailliére Tindall, 1985. 270p.

ÉSSEN-GUSTAVSSON, B. et al. Histochemical properties of muscle fibre types and enzyme activities in skeletal muscle of standardbred trotters of different ages. Equine Vet J, v.12, p.175-180, 1980.

ÉSSEN-GUSTAVSSON, B. et al. Skeletal muscle characteristics of young standardbreeds in relation to growth and early training. In: SNOW, D.H. et al. Equine exercise physiology. Cambridge: Granta Editions, 1983. p.200-210.

HENCKEL, P. Training and growth induced changes in the middle gluteal muscle of young Standardbred trotters. Equine Vet J, v.15, p.134-140, 1983.

LINDHOLM, A. et al. Muscle histochemistry and biochemistry of thoroughbred horses during growth and training. In: SNOW, P.; ROSE, R.J. Equine exercise physiology. Cambridge: Granta, 1983. p.211-217.

NOVIKOFF, A.B. et al. Mitochondrial localization of oxidation enzymes: Staining results with two tetrazolium salts. J Biophys Biochem Cytol, v.9, p.47-61, 1961.

RIVERO, J.L.L. et al. Intramuscular distribution of fibre types in the gluteus medius of the horse: A histochemical analyses. Anatom Histol Embryol, v.22, p.223-240, 1993a.

RIVERO, J.L.L. et al. Changes in cross-sectional area and capillary supply of the muscle fiber population in equine gluteus medius muscle as a function of sample depth. Am J Vet Res, v.54, p.32-37, 1993b.

RIVERO, J.L.L. et al. Activities of selected aerobic and anaerobic enzymes in the gluteus medius of endurance horses with different performance records. Vet Rec, v.137, p.187-192, 1995.

RIVERO, J.L.L. et al. Analysis of myosin heavy chains at the protein level in horse skeletal muscle. J Muscle Res Cell Motil, v.20, p.2121-2221, 1999.

STATISTICAL ANALYSIS SYSTEMS Institute Inc. 2002. SAS User's Guide: Statistics. Cary, NC, 2001. 285p.

SERRANO, A.L. et al. Early long-term changes of equine skeletal muscle in response to endurance training and detraining. Eur J Physio, v.441, p.263-274, 2000.

VAN DEN HOVEN, R. et al. Variation of fiber types in the Triceps brachii, Longissimus dorsi, Gluteus medius, and Biceps femoris of horses. Am J Vet Res, v.46, p.939-941, 1985. 
O arquivo disponível sofreu correções conforme ERRATA publicada no Volume 38 Número 9 da revista. 